УДК $347.787(477)$

DOI https://doi.org/10.32849/2663-5313/2020.11.07

\title{
Олена Чабан,
}

канд. юрид. наук, дочент,

дочент кафедри цивільного права та прочесу

Львівського торговельно-економічного університету

\section{АВТОРСЬКЕ ПРАВО НА АРХІТЕКТУРУ ЗБУДОВАНОГО БАГАТОПОВЕРХОВОГО ЖИТЛОВОГО БУДИНКУ}

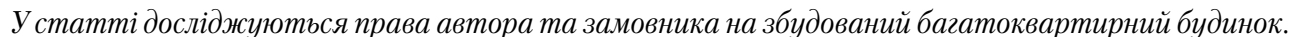
Окреслені суб'єкти авторського права, якими є автор, а також інші фізичні особи та юридичні особи, які набули права на твори відповідно до договору або закону. Вказано, на підставі яких договорів інші суб'єкти можуть набувати прав на твір архітектури.

За основу взята судова справа, за якою відповідача зобов'язали привести у попередній стан фасад будинку у зв'язку з порушенням майнових прав замовника об'єкта архітектури. Проаналізоване поняття «твір архітектури». Визначена основна ознака, яка дозволяє об'єкт архітектури кваліфікувати як об'єкт авторського права. За таких умов твір архітектури підлягає правовій охороні.

Зміст авторського права становлять особисті немайнові та майнові права автора. Проаналізовані відповідні норми законодавства, які визначають обсяг особистих немайнових прав та майнових прав автора. Майнові права автора можуть передаватися замовнику об'єкта архітектури, зміст яких становлять виключне право на використання твору та виключне право на дозвіл або заборону використання твору іншими особами, що передбачено Законом України «Про авторське право і суміжні права». Особисті немайнові права автора не можуть бути відчужені.

За матеріалами коментованої судової справи замовнику об'єкта будівниитва на підставі договору про виконання проєктних робіт передавалися майнові права на об'єкт архітектури. Встановлено перелік можливих майнових прав, які передавалися автором замовнику. Сформульовано, що відповідач порушив не майнові права замовника, коли змінив зовнішній вигляд фасаду житлового багатоквартирного будинку, зробив більші віконні прорізи, а особисті немайнові права автора, а саме право вимагати збереження иілісності твору і протидіяти будь-якому перекрученню, спотворенню чи іншій зміні твору або будь-якому іншому посяганню на твір, що може зашкодити честі і репутаціі автора. Тому саме автор, а не замовник об'єкта архітектури, є особою, яка має право на звернення до суду щодо захисту порушених авторських прав у разі несанкиіонованої зміни цілісності фасаду багатоквартирного житлового будинку як об'єкта авторського права.

Ключові слова: об'єкт авторського права, твір архітектури, суб'єкти авторського права, особисті немайнові права автора, майнові права замовника, власник квартири.

Постановка проблеми. Натепер день склалася така ситуація, що власники квартир у новозбудованому багатоквартирному будинку досить часто хочуть зробити певні поліпшення у квартирі всередині, наслідком чого є зміни вигляду фасаду будинку. Зазвичай, на думку власників квартир, вони мають право склити лоджії, розширювати балкон, змінювати розмір віконних прорізів або вирізати нові вікна тощо. Це призводить до зміни зовнішнього вигляду збудованого багатоквартирного будинку, інакше кажучи, нова архітектурна форма набуває спотвореного вигляду, змінюється архітектурне рішення. Зазвичай усі ці зміни фасаду будинку власники квартир здійснюють самочинно, без наявності відповідних дозволів. Якщо власник квартири вчиняе такі дії, чи ж порушу- ються права автора або замовника твору архітектури як об'єкта авторського права?

Авторське право неодноразово було предметом дослідження і дисертаційних, і монографічних робіт. Над цим працювали такі вчені-цивілісти, як: В. Коссак, І. Якубівський, I. Безклубий, В. Макода, О. Підопригора, Н. Мироненко, Л. Работягова, Ю. Ходико, О. Кочина й інші. Однак мало досліджень, що стосуються такого об'єкта авторського права, як твір архітектури. Ним може бути багатоповерховий житловий будинок у разі дотримання вимог законодавства про право інтелектуальної власності. Окремі вчені 3 вищезазначених досліджували питання поняття твору архітектури як об’єкта авторського права, проте натепер немає досліджень щодо обсягу прав автора та замовника на бага- 
топоверховий житловий будинок як об'єкт авторського права. Тому заявлене наукове дослідження можна вважати актуальним.

Мета статті - визначити обсяг особистих немайнових та майнових прав суб'єктів авторського права на збудований багатоквартирний житловий будинок, з'ясувати, чиї права порушуються (автора чи замовника) у разі зміни власником квартири фасаду будинку.

Виклад основного матеріалу. Відповідно до ч. 1 ст. 433 Цивільного кодексу України (далі - ЦК України), об’єктом авторського права $€$ твір архітектури. Водночас у ст. 1 Закону України «Про авторське право і суміжні права» від 23 грудня 1993 р. (у ред. Закону від 11 липня 2001 р.) твір архітектури - твір у галузі мистецтва спорудження будівель і ландшафтних утворень (креслення, ескізи, моделі, збудовані будівлі та споруди, парки, плани населених пунктів тощо). Згідно з абз. 1 ч. 1 ст. 435 ЦК України, первинним суб'єктом авторського права є автор твору. Суб'єктами авторського права є також інші фізичні особи та юридичні особи, які набули права на твори відповідно до договору або закону. Інші фізичні та юридичні особи можуть набувати авторські права, наприклад, на підставі договору про створення за замовленням і використання об'єкта права інтелектуальної власності, що регулюється нормами ст. 1112 ЦК України, авторського договору, договору на виконання науково-дослідних або дослідноконструкторських та технологічних робіт, що регулюється гл. 62 ЦК України.

Розглянемо матеріали судової справи, у якій встановлено, кому належать авторські права на збудований багатоквартирний житловий будинок. Так, наприклад, рішення Сихівського районного суду м. Львова. Відповідно до обставин справи, Приватне підприємство «Ваш дім Сервіс» (позивач) пред’явило позов до Особи 6 про приведення фасаду будинку в попередній стан та стягнення штрафу в сумі 20000 грн, оскільки відповідач змінив форму віконних прорізів у квартирі, та Товариство з обмеженою відповідальністю (далі - ТОВ) «Житлово-будівельна компанія «Ваш дім»» (третя особа із самостійними вимогами) звернулося до Особи_6 з позовом про приведення фасаду будинку в попередній стан. У п. 13 Договору про надання послуг з управлінням будинку від 28 квітня 2016 р. передбачено, що відповідач зобов'язаний здійснювати засклення лоджій, заміну вікон, встановлення кондиціонерів, антен та інші зміни, які можуть вплинути на зовнішній вигляд житлового будинку, лише за попередньою письмовою згодою забудовника, яким є ТОВ «Житлово-будівельна компанія «Ваш Дім»». Особа, яка вчинила неправомірне втручання у цілісність фасаду, за вимогою управителя (позивача) зобов'язана сплатити штраф у розмірі 20000 грн та усунути таке порушення. Суд дійшов висновку, що в задоволенні позову Приватного підприємства «Ваш дім Сервіс» (управляюча компанія) треба відмовити. Оскільки під час укладення договору про надання послуг з управління будинком були порушені норми Закону України «Про особливості здійснення права власності у багатоквартирному будинку» щодо організації та проведення загальних зборів співвласників будинку. Судові не було надано рішення (протокол) загальних зборів співвласників будинку. Тому договір є недійсним із моменту укладення.

Позов третьої особи, що заявляе самостійні вимоги (ТОВ «Житлово-будівельна компанія «Ваш Дім»»- замовник проєкту) на предмет спору суд задовольнив. Так, відповідач звертався до ТОВ «Житлово-будівельна компанія «Ваш Дім»», яке є власником майнових прав на проєкт будівництва, із заявою про надання дозволу на зміну віконних прорізів, однак останнє відмовило відповідачу в цьому. Договір на виконання проєктних робіт від 11 лютого 2013 р. № 1102-2013 був укладений між ТОВ «Житлово-будівельна компанія «Ваш Дім»» та ТОВ «Неодім Захід», за яким сторони визначили перелік майнових прав, які передаються ТОВ «Житлово-будівельна компанія «Ваш Дім»». Що стосується доводів відповідача про те, що ТОВ «Житлово-будівельна компанія «Ваш Дім»» не набуло майнових прав на об'єкт будівництва, виходячи 3 того, що відповідно до ч. 1 ст. 31 Закону України «Про авторське право та суміжні права» автор (чи інша особа, яка має авторське право) може передати свої майнові права, зазначені у ст. 15 цього Закону, будь-якій іншій особі повністю або частково. Передача майнових прав автора оформляється авторським договором. Суд вказав, що жодним нормативно-правовим актом не визначено, що такий повинен бути викладений окремим документом та не може бути частиною іншого договору, а з аналізу договору від 11 лютого 2013 р. № 1102-2013 та додаткової угоди до нього вбачається, що такий містить усі істотні умови авторського договору та свідчить про передачу авторських прав від ТОВ «Неодім Захід» до ТОВ «Житлово-будівельна компанія «Ваш Дім»» [1].

Особа (особи), творчою працею якої (яких) створено об'єкти архітектури як об'єкти авторського права, уважається автором (співавторами) цих об’єктів (ч. 3 ст. 29 
Закону України «Про архітектурну діяльність»). Як слушно вказують Н. Мироненко, Л. Работягова, не всі об'єкти архітектури (будинки та споруди житлово-цивільного, комунального, промислового й іншого призначення, їх комплекси, об'єкти благоустрою, садово-паркової та ландшафтної архітектури, монументального й монументальнодекоративного мистецтва, території (частини територій) адміністративно-територіальних одиниць і населених пунктів) можна визнати творами архітектури, тобто об'єктами авторського права. Об'єкт архітектури як об'єкт авторського права повинен бути результатом втілення творчої інтелектуальної діяльності особи. Твором архітектури потрібно вважати будь-який твір, що стосується об'єкта архітектури, незалежно від його завершеності, призначення та достоїнств, якщо твір $\epsilon$ результатом творчої праці автора та виражений в об'єктивній формі [2, с. 15]. Поняттям «твори архітектури» охоплюються твори містобудування та садово-паркового мистецтва. Зазначені твори також мають подвійне призначення: вони задовольняють певні потреби людей і водночас розглядаються як художні твори. Правовій охороні піддається саме ця художня сторона. Наприклад, об'єктом авторського права визнається не весь проєкт з усіма його технічними і організаційними рішеннями в натурі, а лише його архітектурна частина [3, с. 701].

Автором об'єкта архітектури є особа, що створила проєкт (документацію для будівництва об'єкта архітектури), якщо він містить творчий задум. Однак не кожен об'єкт архітектури є об'єктом авторського права, тільки той, у який втілено архітектурне рішення. Таким у розумінні абз. 5 ч. 1 ст. 1 Закону України «Про архітектурну діяльність» $є$ авторський задум щодо просторової, планувальної, функціональної організації зовнішнього вигляду й інтер'єру об'єкта архітектури, а також інженерного й іншого забезпечення його реалізації, викладений в архітектурній частині проєкту на всіх стадіях проєктування і зафіксований в будь-якій формі. Такий твір архітектури підлягає правовій охороні.

Зміст авторського права становлять особисті немайнові права та майнові права на об’єкт архітектури як об’єкт авторського права. Згідно із ч. 2 ст. 30 Закону України «Про архітектурну діяльність», майнові права на об'єкт архітектури як об'єкт авторського права, створений за замовленням, належить творцеві цього об'єкта або замовникові спільно, якщо інше не встановлено договором. Ця диспозитивна норма дозволяе автору та замовнику відступити від даного положення і передбачити в договорі, що майнові права на об'єкт архітектури переходять до замовника. Саме так було вказано в договорі на виконання проєктних робіт за вищекоментованою судовою справою, тобто особисті немайнові права належать ТОВ «Неодім Захід», а майнові права - ТОВ «Житлово-будівельна компанія «Ваш Дім»».

Особисті немайнові права на об'єкт архітектури як об'єкт авторського права належать його автору (співавторам) незалежно від умов договору між автором та замовником. Власники квартири в багатоквартирному будинку як об'єкта архітектури, у якому зреалізований авторський задум, мають знати, що авторське право і право власності на матеріальний об'єкт, у якому втілено твір, не залежать одне від одного. Як зазначає Ю. Ходико, головною підставою й аргументом несприйняття права власності на результати інтелектуальної діяльності є те, що класичні правомочності власника забезпечують повноту влади і можливість задовольняти свої потреби й інтереси щодо предметів матеріального світу (речей), але їх неможливо застосувати до результатів, які за своєю природою є нематеріальними благами [4, с. 97]. Згідно ж із ч. 2 ст. 12 Закону України «Про авторське право і суміжні права», власникові матеріального об'єкта, у якому втілено оригінал твору образотворчого мистецтва чи архітектури, не дозволяється руйнувати цей об'єкт без попереднього пропонування його авторові твору за ціну, що не перевищує вартості матеріалів, витрачених на його створення.

У вищезгаданій судовій справі суд першої інстанції задовольнив вимоги замовника ТОВ «Житлово-будівельна компанія «Ваш Дім»», якому належать майнові права на збудований багатоквартирний будинок, зокрема, відповідача зобов'язали привести фасад будинку в попередній стан. Водночас необхідно проаналізувати обсяг майнових прав замовника об'єкта архітектури з метою встановити, яке саме право 3 переліку майнових прав було порушено. Відповідно до ч. 1 ст. 15 Закону України «Про авторське право і суміжні права» до майнових прав автора (чи іншої особи, яка має авторське право) належать: а) виключне право на використання твору; б) виключне право на дозвіл або заборону використання твору іншими особами. Особа, яка має авторське право, може передати свої майнові права будь-якій особі повністю чи частково. Однією з істотних умов такого договору має бути обсяг прав на об'єкт у разі його використання замовником (виключні або невиключні права на використання об'єкта) [5, с. 794]. Отже, якщо за договором на виконання проєктних робіт між ТОВ «Неодім Захід» та ТОВ «Житлова-будівельна компа- 
нія «Ваш Дім»» сторони визначили перелік майнових прав, які передаються ТОВ «Житлова-будівельна компанія «Ваш Дім»», то це $є$ виключне право на використання твору та виключне право на дозвіл або заборону використання твору іншими особами. Тож виникає питання, чи порушив відповідач за коментованою судовою справою права ТОВ «Житлова-будівельна компанія «Ваш Дім»», коли зробив віконні прорізи у фасаді будинку. На нашу думку, порушення майнових прав замовника ТОВ «Житлова-будівельна компанія «Ваш Дім»» не було. В обгрунтування цієї позиції процитуємо ст. 14 Закону України «Про авторське право і суміжні права», де передбачено, що автору належить одне з таких особистих немайнових прав, як вимагати збереження цілісності твору і протидіяти будьякому перекрученню, спотворенню чи іншій зміні твору або будь-якому іншому посяганню на твір, що може зашкодити честі і репутації автора. Як відомо, особисті немайнові права автора не можуть бути передані (відчужені) іншим особам. Тому, на нашу думку, відповідач, коли зробив віконні прорізи у фасаді будинку, порушив особисті немайнові права автора об'єкта архітектури, а саме ТОВ «Неодім Захід».

\section{Висновки}

Зміни фасаду багатоквартирного житлового будинку $є$ порушенням особистих немайнових прав автора об'єкта архітек- тури, за умови, що останній уважається твором архітектури, який містить архітектурне рішення, що підлягає правовій охороні. Тому саме автор, а не замовник об'єкта архітектури, є особою, яка має право на звернення до суду за захистом порушених авторських прав у разі несанкціонованої зміни цілісності фасаду багатоквартирного житлового будинку як об'єкта авторського права. Подальші наукові дослідження будуть присвячені цивільно-правовим способам захисту прав автора твору архітектури від протиправних посягань.

\section{Список використаних джерел:}

1. Рішення № 77687955 від 24 жовтня 2018 р. у справі № 464/8252/17 Сихівського районного суду м. Львова. URL: http://reyestr.court.gov.ua/ Review/77687955.

2. Мироненко Н., Ряботягова Л. Твір архітектури як об'єкт договірних відносин. Теорія і практика інтелектуальної власності. 2013. № 6. С. 10-18.

3. Науково-практичний коментар Цивільного кодексу України : у 2-х т. / за ред. О. Дзери (кер. авт. кол.), Н. Кузнєцової, В. Луця. 4-те вид., перероб. і допов. Київ : Юрінком-Інтер, 2011. Т. І. 808 с.

4. Ходико Ю. Щодо визначення правової природи відносин, що виникають щодо результатів інтелектуальної діяльності. Право і суспільство. 2020. № 4. С. 93-100.

5. Науково-практичний коментар Цивільного кодексу України : у 2-х т. / за ред. О. Дзери (кер. авт кол.), Н. Кузнєцової, В. Луця. 4-те вид., перероб. допов. Київ : Юрінком-Інтер, 2011. Т. II. 1056 с.

Olena Chaban. Copyright to the architectural design of built multistorey apartment house

The article examines the rights of the author and the customer to the built apartment building. The subjects of copyright, which are the author, as well as other individuals and legal entities that have acquired the rights to the works in accordance with the contract or law. It is indicated on the basis of which agreements other subjects can acquire rights to a work of architecture.

The case is based on a lawesuit in which the defendant was obliged to restore the facade of the house in connection with the violation of the property rights of the customer of the architectural object. The concept of "work of architecture" is analyzed. The main feature that allows the object of architecture to be classified as a copyright object is defined. Accordingly, in this case, the work of architecture is subject to legal protection.

The content of copyright consists of personal intangible and property rights of the author. The relevant provisions of the legislation that determine the scope of personal non-property rights and property rights of the author are analyzed. The property rights of the author may be transferred to the customer of the architectural object, the content of which consists of the exclusive right to use the work and the exclusive right to allow or prohibit the use of the work by others, as provided by the Law of Ukraine "On Copyright and Related Rights". Personal non-property rights of the author cannot be alienated.

According to the materials of the commented court case, the property rights to the architectural object were transferred to the customer of the construction object on the basis of the contract on performance of design works. The list of possible property rights which were transferred by the author to the customer is established accordingly. It is stated that the defendant violated not the property rights of the customer by changing the appearance of the facade of a residential apartment building, making larger window openings, and personal non-property rights of the author, namely the right to demand preservation of the work and counteract any distortion, distortion or other alteration.-any other encroachment on the work, which may harm the honor and reputation of the author. Therefore, the author, not the customer of the architectural object, is the person who has the right to go to court to protect the infringed copyright in case of unauthorized change in the integrity of the facade of an apartment building as an object of copyright.

Key words: copyright object, architectural work, copyright subjects, personal non-property rights of author, property rights of customer, apartment owner. 